\title{
Svangerskapskomplikasjoner og risikoen for astma blant nordmenn født 1967-1993
}

\author{
Per Nafstad ${ }^{1,2,3}$, Sven O. Samuelsen ${ }^{1,3}$, Lorentz M. Irgens ${ }^{4}$ og Tor Bjerkedal ${ }^{5}$ \\ 1) Divisjon for epidemiologi, Nasjonalt folkehelseinstitutt, Oslo \\ 2) Høgskolen i Buskerud, Drammen \\ 3) Universitetet $i$ Oslo \\ 4) Medisinsk fødselsregister, Locus for registerepidemiologi, Institutt for samfunnsmedisinske fag, \\ Universitetet $i$ Bergen og Nasjonalt folkehelseinstitutt \\ 5) Rikstrygdeverket, Oslo
}

Adresse for korrespondanse og førsteforfatters nåværende adresse: Per Nafstad, Seksjon for epidemiologi og forebyggende medisin, Institutt for allmenn- og samfunnsmedisin, Det medisinske fakultet, Universitetet i Oslo, Postboks 1030 Blindern, 0318 Oslo Telefon 22850550 E-post: per.nafstad@medisin.uio.no

\section{SAMMENDRAG}

Bakgrunn: Det er mulig at forhold og hendelser i svangerskapet kan påvirke utviklingen av immunog/eller respirasjonssystemet og dermed øke risikoen for å utvikle astma og allergiske lidelser. I denne artikkelen testes hypotesen om hvorvidt svangerskapskomplikasjoner påvirker risikoen for at barn utvikler astma.

Metode: Undersøkelsespopulasjonen består av levende fødte nordmenn født i perioden 1967-1993 ( $\mathrm{n}=1548$ 429). Opplysninger fra Medisinsk fødselsregister (MFR) ble koblet med opplysninger fra Rikstrygdeverket om mottatt grunn- og hjelpestønad. Fødselsregisteret inneholder opplysninger om svangerskapskomplikasjoner og sykdommer hos den gravide/fødende mor og Rikstrygdeverkets register inneholder opplysninger og diagnoser over alle nordmenn som har motatt grunn- og hjelpestønad pga. astma i perioden 1967-1996 $(\mathrm{n}=5938,3,9 / 1000$ personer $)$.

Resultater: Multipell logistisk regresjonsanalyse viste at svangerskapskomplikasjoner (International Classification of Diseases (ICD)-8 kode 630-34) var assosiert med risikoen for å ha fått grunn- og/eller hjelpestønad for astma (odds ratio 1,82, 95\% konfidensintervall: 1,67-1,98). Dette var også tilfelle hvis analysene ble utført i forskjellige strata av fødselsår, pluralitet, atopisk sykdom hos mor, utdanningsnivå hos mor og hvor i landet fødselen fant sted.

Konklusjon: Svangerskapskomplikasjoner hos mor kan gi økt risiko for utvikling av astma hos barnet eller utrykke tidlige tegn på økt risiko for å utvikle sykdommen.

\section{Nafstad P, Samuelsen SO, Irgens LM, Bjerkedal T. Pregnancy complications and risk of asthma in} Norwegians born 1967-1993. Nor J Epidemiol 2005; 15 (1): 47-54.

\section{ENGLISH SUMMARY}

Background: Fetal life events may affect the development of the immune and/or respiratory system and increase the risk of asthma and allergic diseases. The objective of this study was to test the hypothesis that pregnancy complications are associated with the risk of developing asthma in the offspring.

Methods: The study population comprised Norwegian live births 1967-1993 ( $\mathrm{n}=1548$ 429) linking the Medical Birth Registry of Norway (MBRN) (exposure variables) and the National Insurance Administration Register (NIAR) (outcome variables), which covers all Norwegians. The MBRN variables included pregnancy complications, pregnancy outcomes and diseases of the mother. The NIAR provided data on all Norwegians who had received cash benefit for treatment of asthma from 1967 to 1996 ( $\mathrm{n}=5938$, $3.9 / 1000$ persons).

Results: In multiple logistic regression analysis, pregnancy complications (International Classification of Diseases (ICD)-8 codes: 630-34) were associated with the risk of asthma (odds ratio 1.82, 95\% confidence interval: 1.67-1.98). This was also the case if analyses were performed in different strata according to year of birth, plurality, maternal atopy, geographical district of birth, and maternal education.

Conclusions: Pregnancy complications may represent risk factors for the development of asthma in the offspring or express early signs of increased risk for developing the disease.

Artikkelen er basert på:

Nafstad P, Samuelsen SO, Irgens LM, Bjerkedal T. Pregnancy complications and the risk of asthma among

Norwegians born between 1967 and 1993. Eur J Epidemiol 2003; 18: 755-761.

European Journal of Epidemiology har gitt tillatelse til denne publiseringen av materialet. 


\section{INTRODUKSJON}

I de siste tiårene har det vært økende interesse for årsaker til astma og andre atopirelaterte sykdommer. En vesentlig grunn til denne interesse har vært den høye (1-6) og økende (7-10) forekomsten av disse sykdommene. Arv har stor betydning for utviklingen av disse sykdommene $(11,12)$, men undersøkelser har også rapportert at sykdommene er assosiert med svangerskapsrelaterte forhold og eksponeringer tidlig i livet (12-27). Blant annet har det vært vist at fødselsvekt, gestasjonsalder, mors alder, paritet og hodeomkrets ved fødsel er assosiert med en eller flere atopirelaterte tilstander (12-21). Dette har vært tolket som at disse assosiasjonene kan utrykke påvirkning av fosterets immunsystemutvikling. Videre har det vært foreslått at visse typer infeksjoner i svangerskap og i tidlig liv kan påvirke utvikling av disse sykdommene (15-18,21,22,26, 27). En finsk undersøkelse fant sammenhenger mellom mors infeksjoner i svangerskapet og astma blant barna i 7-års alderen (22). En norsk undersøkelse fant at uterusrelaterte svangerskapskomplikasjoner var assosiert med økt risiko for å ha symptomer på astma og allergisk rhinitt ved 4-års alder (26). Studiestørrelsen gjorde det vanskelig å studere effekter av de enkelte svangerskapskomplikasjoner. Også andre undersøkelser har påvist assosiasjoner mellom slike sykdommer og prenatale forhold $(18,21,27)$. En bedre forståelse av slike assosiasjoner kan gi økt kunnskap om årsakene til astma og andre atopirelaterte sykdommer. Denne undersøkelsen har koblet data fra Medisinsk fødselsregister (MFR) fra 1967 til 1993 og data fra Statistisk sentralbyrå med Rikstrygdeverkets register over personer som har mottatt grunn- og hjelpestønad for astma. Registeret dekker hele den norske befolkningen. Målet med undersøkelsen var å teste hypotesen om at mors svangerskapskomplikasjoner er assosiert med risikoen for at barn utvikler astma.

\section{MATERIALE OG METODE}

\section{Studiepopulasjon og datakilder}

MFR inneholder opplysninger om alle levende og dødfødte fra 16. uke svangerskap i Norge etter 1966 $(28,29)$. Denne undersøkelsen omfatter alle barn født levende i perioden 1967 to 1993 ( $\mathrm{n}=1548$ 429) (29). Opplysningene fra MFR ble koblet med Rikstrygdeverkets register over grunn- og hjelpestønad i perioden 1967-96. Fødselsnummeret ble brukt til å koble sammen informasjon fra MFR og Rikstrygdeverket (30). I denne tidsperioden mottok alle nordmenn etter søknad grunn- og hjelpestønad fra Folketrygden hvis de led av kronisk sykdom med behov for spesielt kostnadskrevende behandling eller hjelp (for eksempel i hjemmet). For å motta støtte for astma måtte diagnosen og behandlingsbehovene ha blitt verifisert av en barne- eller lungelege. I grunn- og hjelpestønadsregisteret ble sykdomsdiagnosene registrert ved hjelp av ICD-7 (Inter- national Classification of Diseases) koder til og med 1982 og med ICD-9 koder for resten av perioden, mens MFR brukte ICD-8 koder i hele perioden. Opplysninger om dødsfall og emigrasjon i oppfølgingsperioden er inkludert i datamaterialet, sammen med opplysninger fra Statistisk sentralbyrå om høyeste utdanning for kvinner som fødte mellom 1967 og 1993. Informasjonen om høyeste utdanning har vært oppdatert i 1970, 1980 og hvert år fra resten av perioden. Utdanning registrert nærmest $i$ tid etter fødsel ble brukt som mors utdanning. Registerkoblingene var godkjent av Datatilsynet.

\section{Variabler}

Astma: En person registrert som mottaker av grunnog/eller hjelpestønad med ICD-7 koden 241 før 1983 eller med ICD-9 koden 493 etter 1982 ble definert som å ha astma.

Svangerskapskomplikasjoner: En person registrert i MFR med en eller flere av ICD-8 kodene 630-634, ble definert som å ha hatt en mor med svangerskapskomplikasjon(er). Disse diagnosenumrene er for øvrig ført opp under overskriften svangerskapskomplikasjoner i ICD-8. Svangerskapskomplikasjoner ble videre delt opp i spesifikke kategorier etter ICD-8 kodene: urinveisinfeksjoner (ICD-8:630), ekstrauterint svangerskap (ICD-8:631), blødninger (ICD-8:632) og anemi (ICD8:633). Andre komplikasjoner (ICD-8:634) ble delt inn i grupper som er vanlig å bruke i MFR-undersøkelser: Cervix insuffisiens, placenta dysfunksjon, Rhesusimmunisering og truende tidlig fødsel. Bare komplikasjoner med en hyppighet på mer enn 1000 tilfeller $\mathrm{i}$ hele materialet ble brukt i analysene. Preeklampsi (inkludert eklampsi og svangerskapsforgiftning, ICD8:637) og hyperemesis (ICD-8:638) ble også inkludert $\mathrm{i}$ analysene.

Mors sykdommer: Maternell atopi ble definert som astma (ICD-8:493), atopisk eksem (ICD-8:692) og høysnue ((ICD-8:507) registrert i MFR før eller under svangerskapet. Videre ble følgende sykdommer hos mor i løpet av svangerskapet vurdert: Diabetes mellitus (ICD-8:250), nedre luftveisinfeksjoner (pneumoni ICD-8:480-486 og bronkitt ICD-8:490) og andre infeksjoner (ICD-8:0-136).

Andre forhold hos barn eller mor: Kjønn, fødselsvekt, mors alder, paritet, gestasjonsalder, mors utdanning (<11 år, 11-14 år, 15 år eller mer), fødselsår (1967-74, 1975-83, 1984-93), flerfødsler, enslig mor ved fødsel og mors bosted (Oslo og Akershus, Østlandet utenom Oslo/Akershus, Sørlandet, Vestlandet, Trøndelag og Nord-Norge).

Fødselsvekt $<500 \mathrm{~g}$ og gestasjonsalder $<16$ uker og $>44$ uker ble kodet som manglende opplysninger. Vi ekskluderte barn som var registrert som døde eller emigrerte før de ble 5 måneder gamle og hvis de hadde manglende opplysninger om når de døde eller emigrerte $(\mathrm{n}=14000)$ eller hadde manglende opplysninger om fødselsvekt $(\mathrm{n}=2571)$, paritet $(\mathrm{n}=5582)$ og mors 
alder $(\mathrm{n}=7)$; totalt 7900 . Dette førte til at 1526529 barn ble inkludert i analysene. Manglende opplysninger om gestasjonsalder $(\mathrm{n}=112304)$ og mors utdanning $(\mathrm{n}=47870)$ ble beholdt $\mathrm{i}$ analysene som egne kategorier.

\section{Statistiske metoder}

Logistisk regresjon ble brukt til å beregne justerte odds ratioer for astma og for å vurdere mulige interaksjoner. Fødselsår ble først kodet som dummyvariabler for hvert enkelt år i regresjonsanalysene. På denne måten fikk vi tatt hensyn til at oppfølgingstiden varierer blant personene i undersøkelsen. Responsvariabelen kan dermed tolkes som "current status data" (31) for å ha blitt registrert som mottaker av grunn- og/eller hjelpestønad for astma ved slutten av oppfølgingen. I en annen publikasjon analyserte vi lignende data ved hjelp av Cox-regresjon (29). Noen av modellene i denne artikkelen ble analysert med både Cox-regresjon og logistisk regresjon og resultatene var i praksis identiske. For andre modeller viste det seg å være umulig å bruke Cox-regresjon på grunn av begrensninger i beregningskraft. For å kunne vise resultater som er analysert med samme type regresjonsanalyser, har vi valgt å bare presentere resultater fra logistisk regresjonsanalyser. Manglende beregningskapasitet satte dessuten noen ytterligere begrensninger på hvordan analysene kunne gjennomføres og av denne grunn ble fødselsår kategorisert til 1967-74, 1975-83 og 1984-93 i de endelige justerte analysene. Heller ikke dette påvirket estimater eller konfidensintervaller for analyser som kunne gjennomføres med begge fremgangsmåter.

\section{RESUlTATER}

Til sammen 5938 (3,9 per 1000) nordmenn født mellom 1967 og 1993 hadde mottatt grunn- eller hjelpestønad fra Folketrygden på grunn av astma. Astmaforekomsten økte fra 1,5 per 1000 blant nordmenn født mellom 1967 og 1975, til 3,3 per 1000 blant de født mellom 1976 og 1984 og til 6,9 per 1000 blant de født mellom 1985 og 1993 til tross for den lengre oppfølgingstiden blant de som var født tidligst (i gjennomsnitt 25,5 år hvis de var født 1967-75, 16,5 år hvis de var født 1976-84 og 7,5 år hvis de var født 1985-93), Også atopi blant mødre var blitt mer vanlig for de mødre som fødte sent i perioden, sammenlignet med de som fødte tidligere (tabell 1). Tabell 1 viser også at svangerskapskomplikasjoner, preeklampsi, hyperemesis, men også andre svangerskapsrelaterte forhold varierte i forekomst fra 1967 til 1993. Videre var det en reduksjon av andelen unge mødre og mødre som hadde hatt mange fødsler, mens utdannelsesnivået blant de fødende økte gjennom denne tidsperioden.

Tabell 1. Andelen barn som hadde mødre med atopisk sykdom, svangerskapskomplikasjoner og andre svangerskapsrelaterte forhold etter barnets fødselsår i Norge 1967-93.

\begin{tabular}{lcccc}
\hline & $\begin{array}{c}1967-75 \\
(\mathrm{n}=565585)\end{array}$ & $\begin{array}{c}1976-84 \\
(\mathrm{n}=453339)\end{array}$ & $\begin{array}{c}1985-93 \\
(\mathrm{n}=507605)\end{array}$ & $\begin{array}{c}\text { total } \\
(\mathrm{n}=1526529)\end{array}$ \\
\hline Maternell atopi & 0,014 & 0,047 & 0,078 & 0,045 \\
Svangerskapskomplikasjoner & 0,037 & 0,061 & 0,061 & 0,052 \\
$\quad$ Blødninger & 0,025 & 0,034 & 0,025 & 0,028 \\
$\quad$ Anemi & 0,006 & 0,005 & 0,003 & 0,005 \\
$\quad$ Cervix insuffisiens & 0,002 & 0,005 & 0,002 & 0,003 \\
$\quad$ Placenta dysfunksjon & 0,001 & 0,006 & 0,011 & 0,006 \\
$\quad$ Rhesus immunisering & 0,003 & 0,002 & 0,001 & 0,002 \\
$\quad$ Truende tidlig fødsel & 0,001 & 0,012 & 0,020 & 0,011 \\
Preeklampsi & 0,063 & 0,078 & 0,054 & 0,064 \\
& & & & 0,007 \\
Hyperemesis & 0,006 & 0,007 & 0,008 & \\
Paritet & & & & 0,417 \\
1 & 0,400 & 0,421 & 0,432 & 0,344 \\
2 & 0,322 & 0,365 & 0,350 & 0,160 \\
3 & 0,169 & 0,153 & 0,161 & 0,052 \\
4 & 0,069 & 0,042 & 0,042 & 0,027 \\
5+ & 0,043 & 0,019 & 0,016 & 0,020 \\
Flerfødsler & 0,018 & 0,019 & 0,024 & \\
Mors utdanning & & & & 0,249 \\
$<10$ år & 0,362 & 0,230 & 0,138 & 0,577 \\
$11-14$ år & 0,523 & 0,588 & 0,630 & 0,173 \\
15 år+ & 0,115 & 0,182 & 0,232 & \\
Manglende informasjon & 0,115 & 0,182 & 0,232 & \\
\hline
\end{tabular}


Astma var betydelig mer vanlig hos barn av mødre som hadde atopiske sykdommer (tabell 2). Astmaforekomsten var også avhengig av hvilket år og hvor i landet barnet ble født. Forekomsten av astma var 7,5 per 1000 blant barn som ble født av mødre som hadde hatt en eller flere svangeskapskomplikasjoner, mot 3,7 per 1000 blant barn av mødre som ikke hadde hatt slike komplikasjoner. En eller flere svangerskapskomplikasjoner økte risikoen for å utvikle astma (odds ratio 2,05, 95\% konfidensintervall (KI): 1,88-2,23) (tabell 2). Justert for kjønn, hyperemesis, preeklampsi, mors alder, mors utdanning, paritet, fødselsår, pluralitet, enslig mor ved fødsel, død eller emigrasjon i oppfølgingsperioden, mors bosted, mors atopi, diabetes mellitus, nedre luftveisinfeksjoner og andre infeksjoner i svangerskapet var odds ratio $1,82,95 \% \mathrm{KI}$ : 1,67-1,98. Hvis estimatet også ble justert for gestasjonsalder og fødselsvekt ble odds ratio 1,59, 95\% KI:
1,45-1,74. Analyser for barn født før 1976, barn født mellom 1976 og 1984, og for barn født etter 1984 viste at risikoen for astma var økt for alle tre gruppene med den høyeste beregnede risikoen i den siste gruppen.

Vi utførte stratifiserte analyser blant barn av mødre med og uten en atopisk sykdom (justert odds ratio 1,63, 95\% KI: 1,31-2,04 og 1,85, 95\% KI: 1,69-2,03). Få barn hadde mødre med en atopisk sykdom under svangerskapet. Dette gjorde det vanskelig å studere effekten av svangerskapskomplikasjoner innen denne gruppen barn. Andelen som fikk grunn- og hjelpestønad for astma varierte med hvor i landet en person var født (fra 2,1 til 6,5 per 1000) (tabell 2), men svangerskapskomplikasjoner økte risikoen i alle deler av Norge (justert odds ratio fra 1,61 til 2,09).

Effekten av svangerskapskomplikasjoner ble videre utredet $\mathrm{i}$ analyser av assosiasjonen mellom astma og hver enkelt type komplikasjoner (tabell 3). De fleste

Tabell 2. Kumulativ insidens av astma blant nordmenn født 1967-93 (per 1000) og ujustert (c) og *justert (a) odds ratio (OR) og 95\% konfidensintervall (KI) for astma etter maternelle komplikasjoner i svangerskapet (ICD-8 koder:630-34) (referansekategori: ingen svangerskapskomplikasjoner) samt effektmodifikasjon av pluralitet, fødselsår, maternell atopi, maternell nedre luftveisinfeksjon i svangerskapet, fødedistrikt, og mors utdanning.

\begin{tabular}{|c|c|c|c|c|c|c|}
\hline & $\mathrm{n}$ & $\begin{array}{c}\text { Astma per } \\
1000 \text { personer }\end{array}$ & $\mathrm{cOR}^{*}$ & $95 \% \mathrm{KI}$ & $\mathrm{aOR}^{*}$ & $95 \% \mathrm{KI}$ \\
\hline Totalt, 1967-93 & 1526529 & 3,9 & 2,05 & $1,88-2,23$ & 1,82 & $1,67-1,98$ \\
\hline \multicolumn{7}{|l|}{ Pluralitet } \\
\hline Enkel fødsel & 1495904 & 3,9 & 1,99 & $1,82-2,17$ & 1,78 & $1,63-1,95$ \\
\hline Flerfødsel & 30625 & 5,3 & 2,86 & $2,04-4,00$ & 2,27 & $1,61-3,19$ \\
\hline \multicolumn{7}{|l|}{ Fødselsår } \\
\hline $1967-75$ & 565585 & 1,5 & 1,70 & $1,29-2,24$ & 1,68 & $1,28-2,22$ \\
\hline $1976-84$ & 453339 & 3,3 & 1,63 & $1,38-1,93$ & 1,58 & $1,33-1,87$ \\
\hline $1985-93$ & 507605 & 6,9 & 1,98 & $1,78-2,19$ & 1,97 & $1,77-2,19$ \\
\hline \multicolumn{7}{|l|}{ Maternell atopi } \\
\hline Nei & 1457645 & 3,5 & 2,05 & $1,87-2,25$ & 1,85 & $1,69-2,03$ \\
\hline $\mathrm{Ja}$ & 68884 & 11,9 & 1,62 & $1,30-2,02$ & 1,63 & $1,31-2,04$ \\
\hline \multicolumn{7}{|c|}{ Nedre luftveisinfeksjon i løpet av svangerskapet } \\
\hline Nei & 1522799 & 3,9 & 2,05 & $1,88-2,22$ & 1,82 & $1,67-1,98$ \\
\hline $\mathrm{Ja}$ & 3730 & 8,8 & 1,94 & $0,68-5,57$ & 2,09 & $0,71-6,16$ \\
\hline \multicolumn{7}{|l|}{ **Fødedistrikt } \\
\hline Oslo og Akershus & 303933 & 6,5 & 1,90 & $1,63-2,21$ & 1,74 & $1,49-2,03$ \\
\hline Østlandet utenom Oslo og Akershus & 381102 & 3,9 & 2,24 & $1,91-2,64$ & 2,03 & $1,73-2,41$ \\
\hline Sørlandet & 87078 & 3,1 & 1,58 & $0,98-2,56$ & 1,65 & $1,02-2,68$ \\
\hline Vestlandet & 425382 & 2,1 & 1,89 & $1,50-2,38$ & 1,61 & $1,28-2,03$ \\
\hline Trøndelag & 141382 & 4,0 & 1,88 & $1,44-2,44$ & 1,74 & $1,33-2,27$ \\
\hline Nord-Norge & 187207 & 4,1 & 2,44 & $1,95-3,04$ & 2,09 & $1,67-2,62$ \\
\hline \multicolumn{7}{|l|}{ Mors utdanning } \\
\hline$<11$ år & 368804 & 3,8 & 2,28 & $1,92-2,70$ & 1,84 & $1,55-2,18$ \\
\hline 11-14 år & 853470 & 4,2 & 2,09 & $1,87-2,33$ & 1,83 & $1,64-2,05$ \\
\hline 15 år+ & 256385 & 3,0 & 1,75 & $1,39-2,21$ & 1,72 & $1,36-2,17$ \\
\hline Manglende informasjon & 47870 & 3,0 & 1,66 & $0,96-2,89$ & 1,59 & $0,91-2,76$ \\
\hline
\end{tabular}

* Justert for kjønn, hyperemesis, preeklampsi, mors alder, mors utdanning, paritet, fødselsår, pluralitet, enslig mor ved fødsel, død eller emigrasjon i oppfølgingsperioden, fødedistrikt, mors atopi, diabetes mellitus, nedre luftveisinfeksjoner og andre infeksjoner i svangerskapet.

** 268 barn bodde ikke innen de seks fødedistriktene eller hadde utilstrekkelig informasjon om fødested. 
typer komplikasjoner økte risikoen for astma, (justert odds ratio fra 1,43 til 2,33). Spesielt hyperemesis økte risikoen for astma (justert odds ratio 1,76, 95\% $\mathrm{KI}$ : 1,40-2,21), men ikke preeklampsi (justert odds ratio: 1,08, 95\% KI: 0,97-1,19). Barn av mødre som hadde hatt nedre luftveisinfeksjon under svangerskapet, hadde økt risiko for astma (justert odds ratio 1,71, 95\% KI: 1,21-2,42).

Tabell 4 viser assosiasjoner mellom astma og spesifikke svangerskapskomplikasjoner i tre forskjellige tidsperioder (1967-75, 1976-84 og 1985-93). Funnene var i hovedsak i overensstemmelse med dem en fant når hele materialet ble analysert samlet, men assosiasjonen mellom astma og placentasvikt ble redusert for de yngste kohortene.

\section{DISKUSJON}

Mødres svangerskapskomplikasjoner var assosiert med barns risiko for astma (justert odds ratio 1,82, 95\% KI: 1,67-1,98). Effekten ble observert i forskjellige strata av fødselsår, pluralitet, atopi hos mor, hvor i Norge barnet ble født og mors utdanning.

Resultatene i denne undersøkelsen bekrefter i hovedsak funn fra en tidligere norsk kohortundersøkelse av barn fulgt fra fødsel til 4 års alder (26). Her ble det funnet at uterusrelaterte svangerskapskomplikasjoner var positivt assosiert med risikoen for astma og allergisk rhinitt ved 4 års alder. Helseutfall i denne undersøkelsen var basert på foreldrenes rapportering av å ha et barn med astma og allergisk rhinitt diagnos-

Tabell 3. Kumulativ insidens for astma blant nordmenn født 1967-93 (per 1000) samt ujustert (c) og *justert (a) odds ratio (OR) og 95\% konfidensintervall (KI) for å ha astma etter maternelle svangerskapskomplikasjoner. Referansekategori: ikke gjeldende komplikasjon f.eks. blødninger.

\begin{tabular}{|c|c|c|c|c|c|c|}
\hline & $\mathrm{n}$ & $\begin{array}{c}\text { Astma per } \\
1000 \text { personer }\end{array}$ & $\mathrm{cOR}$ & $95 \% \mathrm{KI}$ & $\mathrm{aOR}$ & $95 \% \mathrm{KI}$ \\
\hline \multicolumn{7}{|l|}{ Svangerskapskomplikasjoner: } \\
\hline Blødninger & 42333 & 5,8 & 1,51 & $1,33-1,72$ & 1,43 & $1,26-1,63$ \\
\hline Anemi & 7079 & 6,1 & 1,57 & $1,16-2,11$ & 1,67 & $1,24-2,36$ \\
\hline Cervix insuffisiens & 4635 & 7,8 & 2,01 & $1,45-2,79$ & 1,75 & $1,26-2,45$ \\
\hline Placenta dysfunksjon & 8664 & 9,7 & 2,53 & $2,04-3,14$ & 1,68 & $1,35-2,09$ \\
\hline Rhesus immunisering & 3664 & 5,2 & 1,34 & $0,85-2,10$ & 1,58 & $1,01-2,49$ \\
\hline Truende tidlig fødsel & 16300 & 13,4 & 3,57 & $3,11-4,09$ & 2,33 & $2,02-2,68$ \\
\hline Preeklampsi & 98188 & 4,0 & 1,03 & $0,93-1,14$ & 1,08 & $0,97-1,19$ \\
\hline Hyperemesis & 10698 & 7,1 & 1,86 & $1,49-2,34$ & 1,76 & $1,40-2,21$ \\
\hline
\end{tabular}

*Justert for kjønn, hyperemesis, preeklampsi, mors alder, mors utdanning, paritet, fødselsår, pluralitet, enslig mor ved fødsel, død eller emigrasjon i oppfølgingsperioden, fødedistrikt, mors atopi, diabetes mellitus, nedre luftveisinfeksjoner og andre infeksjoner i svangerskapet. Også justert for andre svangerskapskomplikasjoner.

Tabell 4. Justert* (a) odds ratio (OR) og 95\% konfidensintervall (KI) for å ha astma etter spesifikke svangerskapskomplikasjoner, preeklampsi og hyperemesis i tre forskjellige fødselsårsperioder i Norge 1967-93.

\begin{tabular}{|c|c|c|c|c|c|c|}
\hline & \multicolumn{6}{|c|}{ Fødeår } \\
\hline & \multicolumn{2}{|c|}{$1967-75$} & \multicolumn{2}{|c|}{ 1976-84 } & \multicolumn{2}{|c|}{$1985-93$} \\
\hline & $\mathrm{aOR}$ & $95 \% \mathrm{KI}$ & $\mathrm{aOR}$ & $95 \% \mathrm{KI}$ & $\mathrm{aOR}$ & $95 \% \mathrm{KI}$ \\
\hline \multicolumn{7}{|c|}{ Svangerskapskomplikasjoner: } \\
\hline Blødninger & 1,48 & $1,04-2,12$ & 1,33 & $1,05-1,98$ & 1,49 & $1,25-1,77$ \\
\hline Anemi & 2,19 & $1,23-3,88$ & 0,90 & $0,45-1,80$ & 2,12 & $1,40-3,22$ \\
\hline Cervix insuffisiens & 0,49 & $0,07-3,49$ & 2,21 & $1,37-3,54$ & 1,69 & $1,04-2,74$ \\
\hline Placenta dysfunksjon & 5,91 & $2,18-16,02$ & 2,70 & $1,80-4,06$ & 1,39 & $1,06-1,81$ \\
\hline Rhesus immunisering & 1,45 & $0,54-3,87$ & 1,68 & $0,75-3,76$ & 1,71 & $0,88-3,30$ \\
\hline Truende tidlig fødsel & 2,04 & $0,51-8,24$ & 1,59 & $1,12-2,24$ & 2,58 & $2,21-3,01$ \\
\hline Preeklampsi & 1,22 & $0,95-1,57$ & 0,98 & $0,82-1,18$ & 1,10 & $0,95-1,27$ \\
\hline Hyperemesis & 1,39 & $0,69-2,79$ & 1,58 & $0,99-2,53$ & 1,92 & $1,44-2,54$ \\
\hline
\end{tabular}

*Justert for kjønn, hyperemesis, preeklampsi, mors alder, mors utdanning, paritet, fødselsår, pluralitet, enslig mor ved fødsel, død eller emigrasjon i oppfølgingsperioden, fødedistrikt, mors atopi, diabetes mellitus, nedre luftveisinfeksjoner og andre infeksjoner i svangerskapet. Også justert for andre svangerskapskomplikasjoner. 
tisert av en lege og som hadde hatt symptomer på sykdommen i løpet av det siste året. Det var få personer som hadde mottatt grunn- og/eller hjelpestønad på grunn av allergisk rhinitt. Vi kunne derfor ikke analysere tilsvarende sammenhenger for allergisk rhinitt $i$ dette materialet. Slik astma har blitt definert i denne undersøkelsen må en kunne anta at diagnosen vesentlig omfatter alvorlige og kroniske eller langvarige respirasjonsproblemer som har blitt diagnostisert av barne- eller lungelege og som har ført til betydelige utgifter. Den lave forekomsten av astma tyder også på at dette er tilfelle. Derfor vil referansegruppen inneholde personer med mildere former av astma, noe som vanligvis vil kunne føre til en underestimering av risikoen. I dette tilfelle vil det sannsynligvis bli kompensert av det store antallet personer i referansegruppen. Registreringen av svangerskapskomplikasjoner ble gjort ved alle fødeavdelinger i Norge og konvertert til ICD-8 koder og standardkoder i bruk ved Medisinsk fødselsregister. Lokale rutiner ved fødeavdelingene og endringer $\mathrm{i}$ rutiner og oppmerksomhet over tid kan derfor ha påvirket registreringen, men registreringene ble gjort uavhengig av og i tid før utvikling av de aktuelle helseutfallene. Dette gjør det lite sannsynlig at mulig feilklassifisering skulle være differensielt relatert til den senere utviklingen av astma.

Til tross for kortere observasjonstid økte forekomsten av astma fra de tidligste til de seneste kohortene. Denne observasjonen passer godt sammen med rapporter fra mange land om økende forekomst av astma (79) inkludert en registrering av funksjonsnedsetting på grunn av astma blant barn i USA fra 1969 til 1996 (32). Til tross for disse observasjonene kan en neppe se bort fra at endringer i diagnostiske kriterier og oppmerksomhet om astma kan ha bidratt til endringene. Dette vil også kunne forklare variasjonene i astmaforekomsten $\mathrm{i}$ forskjellige distrikter i Norge og indikerer at astma kan være et heterogent helseutfall som kan være avhengig av både når og hvor en er født eller vokser opp. Mors svangerskapskomplikasjoner representerte allikevel en konsistent overrisiko uansett fødselsår og fødested. Det var en firedobling av astma blant barn av mødre med atopisk sykdom, selv om atopi blant mødrene sannsynligvis var underrapportert.

I bivariate analyser doblet svangerskapskomplikasjoner risikoen for astma hos barna. Hvis risikoen ble justert for andre svangerskapsrelaterte forhold, fødselsår og i tillegg sykdommer hos mødre og andre kovariater, ble odds ratio redusert fra 2,05 til 1,82. Hvis en $\mathrm{i}$ tillegg justerte for fødselsvekt og gestasjonsalder ble effekten ytterligere redusert. Siden svangerskapskomplikasjoner kan påvirke fødselsvekst og svangerskapslengde er det diskutabelt om slike justeringer bør utføres da det kan føre til underestimering av risiko. Sosiale forhold som mors utdanning og ekteskapelig status/ samboerskap påvirket ikke sammenhengen mel- lom svangerskapskomplikasjoner og astma hos barnet. Vi kunne ikke justere for mors røyking, men mors røyking påvirket ikke de tilsvarende assosiasjonene i den andre norske undersøkelsen som har studert tilsvarende forhold (26).

Gjennomsnittlig observasjonstid for deltagerne født i tiden etter 1984 var 7,5 år. Dette betydde at for de yngste kohortene var det utelukkende barneastma som ble studert, og i disse kohortene var sammenhengen mellom svangerskapskomplikasjoner og astma sterkest. Dette kan bety at svangerskapskomplikasjoner er spesielt viktig for utviklingen av barneastma eller at risikoprofilen for astma har endret seg over tid.

Vi forsøkte å studere effektene av de enkelte svangerskapskomplikasjonene i mer detalj. Alle komplikasjonene unntatt preeklampsi syntes å øke risikoen for astma. I de enkelte fødselsårsstrata ble bildet mer komplekst. Forklaringen på dette var antagelig både korrelasjoner mellom de enkelte svangerskapskomplikasjonene, redusert statistisk styrke og variasjoner i rapportering mellom de enkelte tidsperiodene. Analysene kunne derfor ikke bidra til å identifisere spesielle komplikasjoner som kunne peke mot en spesiell biologisk hypotese. Funnene tydet heller på at slike komplikasjoner kan ha en generell påvirkning på fostervekst og utvikling eller at mødre av barn med økt risiko for å få astma har en økt risiko for å utvikle svangerskapskomplikasjoner generelt. Videre kan en spekulere på om det å ha svangerskapskomplikasjoner kan samvariere med for eksempel suboptimal ernæring i svangerskapet, separasjon mellom mor og barn, mikrobiologisk eksponering, antibiotika behandling etc. som igjen kunne påvirke risikoen for utvikling av astma hos barnet senere i livet.

Hyperemesis, men ikke preeklampsi synes å øke risikoen for astma hos barnet. Disse funnene var delvis i uoverensstemmelse med et tidligere funn (26), men kan kanskje forklares med utilstrekkelig statistisk styrke i den foregående undersøkelsen. Vi fant også at det å ha hatt en nedre luftveisinfeksjon under svangerskapet økte risikoen for at barnet fikk astma. Det kan forklares med at infeksjoner i morens luftveier kan bety økt stress for barnet, eller at slike symptomer uttrykker en genetisk disposisjon i mor og foster.

Funnene i denne undersøkelsen støtter hypotesen om at svangerskapskomplikasjoner inkludert hyperemesis øker risikoen for at barnet kan utvikle astma. Mange forskjellige svangerskapskomplikasjoner var positivt assosiert med risikoen for astma og undersøkelsen kunne således ikke bidra til å peke mot en spesifikk biologisk forklaring for assosiasjonene. Det er mulig at svangerskapskomplikasjoner kan representere generelt stress for fosteret eller at de er tidlige indikatorer på at fosteret har økt risiko for å utvikle sykdommen. Assosiasjonene er sterke og tilsier at en bør forsøke å finne mekanismene bak disse funnene. 


\section{REFERANSER}

1. The International Study of Asthma and Allergies in Childhood (ISAAC) Steering Committee. Worldwide variation in prevalence of symptoms of asthma, allergic rhinoconjunctivitis, and atopic eczema: ISAAC. Lancet 1998; 351: 1225-1232.

2. Pearce N, Sunyer J, Cheng S, Chinn S, Bjorksten B, Burr M, Keil U, Anderson HR, Burney P. Comparison of asthma prevalence in the ISAAC and the ECRHS. ISAAC Steering Committee and the European Community Respiratory Health Survey. International Study of Asthma and Allergies in Childhood. Eur Respir J 2000; 16: 420-426.

3. Sunyer J, Anto JM, Tobias A, Burney P. Generational increase of self-reported first attack of asthma in fifteen industrialized countries. European Community Respiratory Health Study (ECRHS). Eur Respir J 1999; 14: 885-891.

4. Turkeltaub PC, Gergen PJ. Prevalence of upper and lower respiratory conditions in the US population by social and environmental factors: data from the second National Health and Nutrition Examination Survey, 1976 to 1980 (NHANES II). Ann Allergy 1991; 67: 147-154.

5. Mannino DM, Gagnon RC, Petty TL, Lydick E. Obstructive lung disease and low lung function in adults in the United States: data from the National Health and Nutrition Examination Survey, 1988-1994. Arch Intern Med 2000; 160: 1683-1689.

6. Yeatts K, Shy C, Wiley J, Music S. Statewide adolescent asthma surveillance. J Asthma 2000; 37: 425-434.

7. Burr ML, Butland BK, King S, Vaughan-Williams E. Changes in asthma prevalence: two surveys 15 years apart. Arch Dis Child 1989; 64: 1452-1456.

8. Jarvis D, Burney P. The epidemiology of allergic diseases. BMJ 1998; 316: 607-610.

9. Strachan DP. The epidemiology of childhood asthma. Allergy 1999; 54: 7-11.

10. Downs SH, Marks GB, Sporik R, Belosouva EG, Car NG, Peat JK. Continued increase in the prevalence of asthma and atopy. Arch Dis Child 2001; 84: 20-23.

11. Harris JR, Magnus P, Samuelsen SO, Tambs K. No evidence for effects of family environment on asthma. A retrospective study of Norwegian twins. Am J Respir Crit Care Med 1997; 156: 43-49.

12. Steffensen FH, Sorensen HT, Gillman MW, Rothman KJ, Sabroe S, Fischer P, Olsen J. Low birth weight and preterm delivery as risk factors for asthma and atopic dermatitis in young adult males. Epidemiology 2000; 11: $185-188$.

13. Darlow BA, Horwood LJ, Mogridge N. Very low birthweight and asthma by age seven years in a national cohort. Pediatr Pulmonol 2000; 30: 291-296.

14. Fergusson DM, Crane J, Beasley R, Horwood LJ. Perinatal factors and atopic disease in childhood. Clin Exp Allergy 1997; 27: 1394-1401.

15. Martinez FD. Maternal risk factors in asthma. Ciba Found Symp 1997; 206: 233-243.

16. Sears M. Epidemiology of childhood asthma. Lancet 1997; 350: 1015-1020.

17. Björksten B. Risk factors in early childhood for the development of atopic diseases. Allergy 1994; 49: 400407.

18. Strachan DP, Butland BK, Anderson HR. Incidence and prognosis of asthma and wheezing illness from early childhood to age 33 in a national British cohort. BMJ 1996; 312: 1195-1199.

19. Bråbäck L, Hedberg A. Perinatal risk factors for atopic disease in conscripts. Clin Exp Allergy 1998; 28: 936942.

20. Leadbitter P, Pearce N, Cheng S, Sears MR, Holdaway MD, Flannery EM, Herbison GP, Beasley R. Relationship between fetal growth and the development of asthma and atopy in childhood. Thorax 1999; 54: 905-910.

21. Xu B, Jarvelin MR, Pekkanen J. Prenatal factors and occurrence of rhinitis and eczema among offspring. Allergy 1999; 54: 829-836.

22. Xu B, Pekkanen J, Jarvelin MR, Olsen P, Hartikainen AL. Maternal infections in pregnancy and the development of asthma among offspring. Int J Epidemiol 1999; 28: 723-727.

23. Stein RT, Sherrill D, Morgan WJ, Holberg CJ, Halonen M, Taussig LM, Wright AL, Martinez FD. Respiratory syncytial virus in early life and risk of wheeze and allergy by age 13 years. Lancet 1999; 354: 541-545.

24. von Mutius E, Illi S, Hirsch T, Leupold W, Keil U, Weiland SK. Frequency of infections and risk of asthma, atopy and airway hyperresponsiveness in children. Eur Respir J 1999; 14: 4-11.

25. Ponsonby AL, Couper D, Dwyer T, Carmichael A, Kemp A. Relationship between early life respiratory illness, family size over time, and the development of asthma and hay fever: a seven year follow up study. Thorax 1999; 54: 664-669.

26. Nafstad P, Magnus P, Jaakkola JJK. Pregnancy complications and childhood asthma and allergic rhinitis. $J$ Allergy Clin Immunol 2000; 106: 867-873. 
27. Annesi-Maesano I, Moreau D, Strachan D. In utero and perinatal complications preceding asthma. Allergy 2001; 56: 491-497.

28. Irgens LM. The Medical Birth Registry of Norway. Epidemiological research and surveillance throughout 30 years. Acta Obstet Gynecol Scand 2000; 79: 435-439.

29. Nafstad P, Samuelsen SO, Irgens LM, Bjerkedal T. Birth weight and hearing impairment in Norwegians born from 1967 to 1993. Pediatrics 2002; 110(3): e30.

30. The Norwegian Social Insurance Scheme. Royal Ministry of Health and Social Affairs 2000. ISSN 08090696.

31. Shiboski SC. Generalized additive models for current status data. Lifetime Data Analysis 1998; 4: 29-50.

32. Newacheck PW, Halfon N. Prevalence, impact, and trends in childhood disability due to asthma. Arch Pediatr Adolesc Med 2000; 154: 287-293. 